\title{
Major bulk dissolved organic carbon (DOC) removal by encrusting coral reef cavity sponges
}

\author{
Jasper M. de Goeij ${ }^{1,3, *}$, Herbert van den Berg ${ }^{1,3}$, Martine M. van Oostveen ${ }^{1,3}$, \\ Eric H. G. Epping ${ }^{2}$, Fleur C. van Duyl ${ }^{1}$ \\ ${ }^{1}$ Department of Biological Oceanography, and ${ }^{2}$ Department of Marine Chemistry \& Geology, \\ Royal Netherlands Institute for Sea Research, PO Box 59, 1790 AB Den Burg, Texel, The Netherlands \\ ${ }^{3}$ The CARMABI Foundation, Caribbean Research \& Management of Biodiversity, PO Box 2090, Willemstad, Curaçao, \\ Netherlands Antilles
}

\begin{abstract}
We studied the removal of dissolved organic carbon (DOC) and bacterioplankton by the encrusting sponges Halisarca caerulea, Mycale microsigmatosa and Merlia normani in coral reefs along Curaçao, Netherlands Antilles. Sponge specimens were collected from coral reef cavities and incubations were done on the fore-reef slope at $12 \mathrm{~m}$ depth. The concentrations of DOC and bacterioplankton carbon (BC) were monitored in situ, using incubation chambers with sponges and without sponges (incubations with coral rock or ambient reef water only). Average $( \pm \mathrm{SD}) \mathrm{DOC}$ removal rates (in $\mu \mathrm{mol} \mathrm{C} \mathrm{cm}^{-3}$ sponge $\mathrm{h}^{-1}$ ) amounted to $13.1 \pm 2.5,15.2 \pm 0.9$ and $13.6 \pm 2.4$ for $H$. caerula, $M$. microsigmatosa and $M$. normani, respectively. The DOC removal rates by the 3 sponges were on average 2 orders of magnitude higher than BC removal rates and accounted for more than $90 \%$ of the total organic carbon removal. Total organic carbon removal rates presented here were the highest ever reported for sponges. In an additional experiment with $H$. caerulea, the fate of organic carbon was reconstructed by measuring dissolved oxygen $\left(\mathrm{O}_{2}\right)$ removal and dissolved inorganic carbon (DIC) release in a laminar flow chamber. $H$. caerulea respired 39 to $45 \%$ of the organic carbon removed. The remaining 55 to $61 \%$ of carbon is expected to be assimilated. We argue that $H$. caerulea may have a rapid turnover of matter. All 3 sponge species contained associated bacteria, but it is unclear to what extent the associated bacteria are involved in the nutrition of the sponge. We conclude that the 3 sponge-microbe associations are (related to the availability of dissolved and particulate carbon sources in the ambient water) 'dissolved organic matter (DOM)-feeders' and encrusting sponges are of quantitative importance in the removal of DOC in coral reef cavities.
\end{abstract}

KEY WORDS: DOC · Sponges · Nutrition · Carbon budget · Nutrient cycling • Coral reef · Reef framework cavities · Caribbean · Curaçao

\section{INTRODUCTION}

Sponges are considered very efficient suspension feeders and their filtering capacity in combination with their abundance may have a profound impact on their environment (Gili \& Coma 1998). Sponges can feed on a wide variety of types and sizes of plankton up to the capture of zooplankton (Vacelet \& Boury-Esnault 1995). However, the preferred utilization of nano- and picoplankton (particles $<2 \mu \mathrm{m}$ ) by sponges has been shown both in laboratory studies (Van de Vyver et al.
1990, Riisgård et al. 1993, Turon et al. 1997) and field studies (e.g. Reiswig 1974a, Pile et al. 1996, Ribes et al. 1999, Kötter \& Pernthaler 2002).

There is still debate on the qualitative and quantitative role of dissolved organic matter (DOM) in the nutrition of marine benthic animals (Wright \& Manahan 1989, Thomas 1997). As early as 1872, it was suggested that DOM could be a potential food source for marine invertebrates and ever since it has remained a topic for discussion (reviewed by Jørgensen 1976). Reiswig pioneered studies on the retention of 
organic carbon by sponges (Reiswig 1971) and the vast volumes of water sponges can process over time (Reiswig 1974b). He found a discrepancy between the supply and demand of carbon in benthic suspension feeders, and DOM was proposed to be the missing link (Reiswig 1981). It is generally assumed that only sponges with sponge-associated bacteria, sometimes comprising up to half of the total biomass of the sponge, are capable of utilizing DOM (Frost 1987, Ribes et al. 1999). Sponges have been demonstrated to take up the amino acid glycine (Stephens \& Schinske 1961), $0.1 \mu \mathrm{m}$ beads (Leys \& Eerkes-Medrano 2006), as well as virus particles (Hadas et al. 2006) from ambient water. Both viral particles and $0.1 \mu \mathrm{m}$ beads easily pass a $0.2 \mu \mathrm{m}$ filter and are therefore operationally defined as 'dissolved'. Yahel et al. (2003) were the first to show extensive removal of bulk dissolved organic carbon (DOC) by the sponge Theonella swinhoei. The DOC intake by this sponge accounted for more than $90 \%$ of the total organic carbon (TOC) intake.

Coral cavities, ranging from 50 to $250 \mathrm{dm}^{3}$, have been identified as major sinks of organic carbon (De Goeij \& Van Duyl 2007). Framework cavities in reefs of the Berau area, East Kalimantan, Indonesia and in the reefs of Curaçao, Netherlands Antilles have shown extensive removal of organic carbon. The surface of the framework exceeds that of the open reef (Richter et al. 2001, Scheffers et al. 2004) and the cavity walls are densely covered with cryptic organisms, dominated by (mostly encrusting) sponges. The natural sponge coverage in relation to the total cavity surface (including the sandy bottom) in coral cavities ranges from 10 to $27 \%$ (Wunsch et al. 2000, Richter et al. 2001, Van Duyl et al. 2006). Particle uptake from the water column by the benthic reef community is mainly accounted for by suspension feeders, such as sponges and ascidians (Ribes et al. 2005). Encrusting cryptic sponges feed effectively on ultraplankton (more than $90 \%$ accounted for by bacteria) resulting in high carbon fluxes, up to $373 \mathrm{mg} \mathrm{C} \mathrm{g}$ ash free dry weight (AFDW) ${ }^{-1} \mathrm{~d}^{-1}$ (Kötter \& Pernthaler 2002). However, although particulate organic carbon (POC) removal rates by the cryptic habitat are considered to be high (Richter et al. 2001, Scheffers et al. 2004), DOC removal rates by coral cavities were 2 orders of magnitude higher in comparison (De Goeij \& Van Duyl 2007). No efforts have been made to investigate the contribution of DOC to total carbon uptake by encrusting sponges in coral cavities.

In this study we investigate the role of 3 encrusting coral cavity sponge species, Halisarca caerulea, Mycale microsigmatosa and Merlia normani, in the removal of DOC and bacterioplankton carbon (BC). For $H$. caerulea, the fate of organic carbon was further studied by measuring dissolved oxygen $\left(\mathrm{O}_{2}\right)$ consumption and DIC release.

\section{MATERIALS AND METHODS}

Study area and sponge collection. The study was conducted on the Caribbean island of Curaçao, Netherlands Antilles $\left(12^{\circ} 12^{\prime} \mathrm{N}, 68^{\circ} 56^{\prime} \mathrm{W}\right)$. Sponge experiments were performed at station Buoy 1 using incubation chambers on the reef flat of the fringing reefs along the leeward side of Curaçao at a depth of approximately $12 \mathrm{~m}$ (Fig. 1). Sponges were collected by chiseling them from overhangs and cavity walls between 15 to $25 \mathrm{~m}$ depth. Attached pieces of coral rock were cleared of epibionts and shaped to a maximum total volume of approximately $70 \mathrm{~cm}^{3}$ and a sponge surface of approximately $24 \mathrm{~cm}^{2}$, with an average sponge thickness of $2.5 \mathrm{~mm}$. Sponges were stored upside down in wire cages $\left(20 \times 20 \times 15 \mathrm{~cm}_{\text {; }}\right.$ maximum of 4 pieces per cage) to protect them from sediment accumulation and predation. Cages were stored inside coral reef cavities at $15 \mathrm{~m}$ depth. Sponges were acclimatized for at least $1 \mathrm{wk}$ prior to experiments. Pieces of sponge were kept for a maximum of 6 mo before use in an incubation experiment. They were regularly checked and when necessary the substratum was cleaned and debris removed. Sponges were re-sized by cutting them to their original surface area when overgrowth of the edges of the coral rock substratum by the sponge occurred. After each experiment 2 pieces of sponge tissue $\left(0.5 \mathrm{~cm}^{2}\right)$ were cut loose from the substratum and fixed for both taxonomy and the determination of abundance of sponge-associated bacteria. Sponge and all data collection were made via SCUBA diving.

Incubation chambers. Two types of incubation chambers were used in situ to determine DOC and BC removal over time for the selected sponges. During the

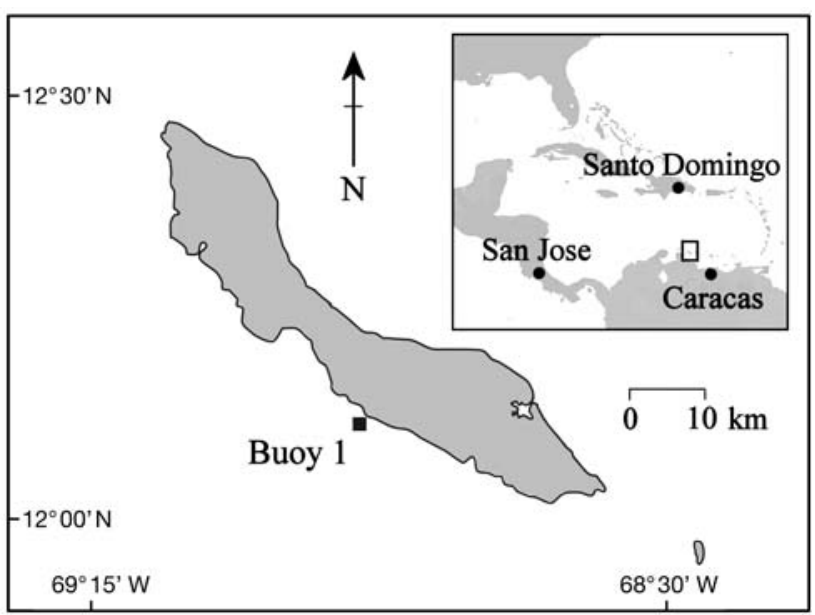

Fig. 1. Location of the Buoy 1 station on the SW coast of Curaçao. Inset: location of Curaçao in the Caribbean Sea. The long-term mean current runs from SE to NW along the island 
first fieldwork period (2004) we used 1.05 l Plexiglass cylinders with a magnetic stirring device, powered by a $9 \mathrm{~V}$ battery (Fig. 2). Sample water withdrawn from the chamber during incubation was replaced by air, supplied by an air-filled bottle attached to the cylinder. Air was supplied and flow was controlled by a 3-way valve and clamps, which were opened during sampling. Pieces of sponge ( 7.7 to $31.2 \mathrm{~cm}^{2}$ ) were placed on the bottom of the cylinder next to the magnetic stirrer and sampling point. The cylinder was sealed by two $10 \mathrm{~cm}$ diameter lids containing an O-ring. This incubation chamber will be referred to as Chamber 1 .

To measure $\mathrm{O}_{2}$ and dissolved inorganic carbon (DIC) fluxes in the sponge Halisarca caerulea we designed a portable Plexiglass flow chamber. The design of the flow chamber is given in Fig. 3. The flow chamber $(35 \times 8 \times 12 \mathrm{~cm})$ has a volume of $1.7 \mathrm{l}$ and an average flow velocity of approximately $1.5 \mathrm{~cm} \mathrm{~s}^{-1}$, generated by a magnetic stirrer, powered by 8 AA batteries (total $12 \mathrm{~V})$. Downstream the stirrer, water passes a mesh screen with $2 \mathrm{~mm}$ pores, to reduce vortices and to create a quasi-laminar flow. Water was sampled downstream of the sponge, using a glass Pasteur pipette and a silicon tube. The sample water was replaced by ambient reef water through a PVC tube ( $2 \mathrm{~mm}$ in diameter and $0.5 \mathrm{~m}$ in length to reduce diffusive exchange) placed after the magnetic stirring device. The surface area of the sponge compartment $(6.5 \times$ $4.5 \times 3 \mathrm{~cm}$ ) relative to the volume of the chamber was scaled to the proportion of sponge surface on total cavity surface area (TSA) and coral cavity volume (CV). The empirical linear relation of $\mathrm{CV}\left(\mathrm{dm}^{3}\right)$ and TSA $\left(\mathrm{m}^{2}\right)$ in coral cavities on Curaçao (for cavity volumes ranging from 86 to $248 \mathrm{dm}^{3}$ ) is described as: TSA $=0.0108 \times \mathrm{CV}$
$+0.4598\left(\mathrm{R}^{2}=0.943, \mathrm{n}=7, \mathrm{p}<0.001\right)$ (De Goeij \& Van Duyl 2007). If CV is assumed to be $1.7 \mathrm{l}$, a sponge surface area of $24.5 \mathrm{~cm}^{2}$ used in the flow chamber corresponds to a sponge cover of approximately $11 \%$ of the TSA. Pieces of coral rock with sponge were shaped to the size of the sponge compartment and sponges were cut to a surface area of $24.5 \mathrm{~cm}^{2}\left(6.1 \mathrm{~cm}^{3}\right)$. The incubation chamber was sealed with a $10 \mathrm{~cm}$ diameter lid containing an O-ring. This laminar flow chamber will be referred to as Chamber 2. Both Chambers 1 and 2 were covered with duct tape and a black bag in order to conduct the experiments in the dark.

Sample collection. In a first series of experiments, changes in DOC concentration and bacterial abundance (BA) were measured over time in Chamber 1 to determine DOC and BC removal by the encrusting cavity-dwelling sponges Halisarca caerulea ( $\mathrm{n}=7$ ), Mycale microsigmatosa $(\mathrm{n}=6)$, and Merlia normani ( $\mathrm{n}=3$ ) (Fig. 4). Incubations with only ambient reef water were performed as a blank measurement (control). In addition, incubation experiments were performed with a piece of coral rock (cleared of epibionts) to measure possible coral rock metabolism. Differences in DOC and $\mathrm{BC}$ removal rates between the 3 sponges were determined. Experiments were conducted between March and September 2004 between 10:00 and 12:00 h. Prior to the experiment, pumping activity of the sponges was checked and only specimens with open oscula (outflow openings) were selected for the experiments. Sponges were carefully positioned, and after closing the chamber, water samples were taken at time $(t)=0,2,4,10,30$ and in some series up to $45 \mathrm{~min}$. Samples for DOC and BA were taken with acid washed $100 \mathrm{ml}$ polycarbonate
Fig. 2. Incubation Chamber 1 . Pieces of sponge are placed in the chamber and water is mixed by a magnetic stirrer. During the sampling process, sample water is replaced by air from the bottle attached underneath the benthic chamber. The chamber is sealed from outside water by a lid with an O-ring. Air release is regulated by a 3 -way valve and clamps
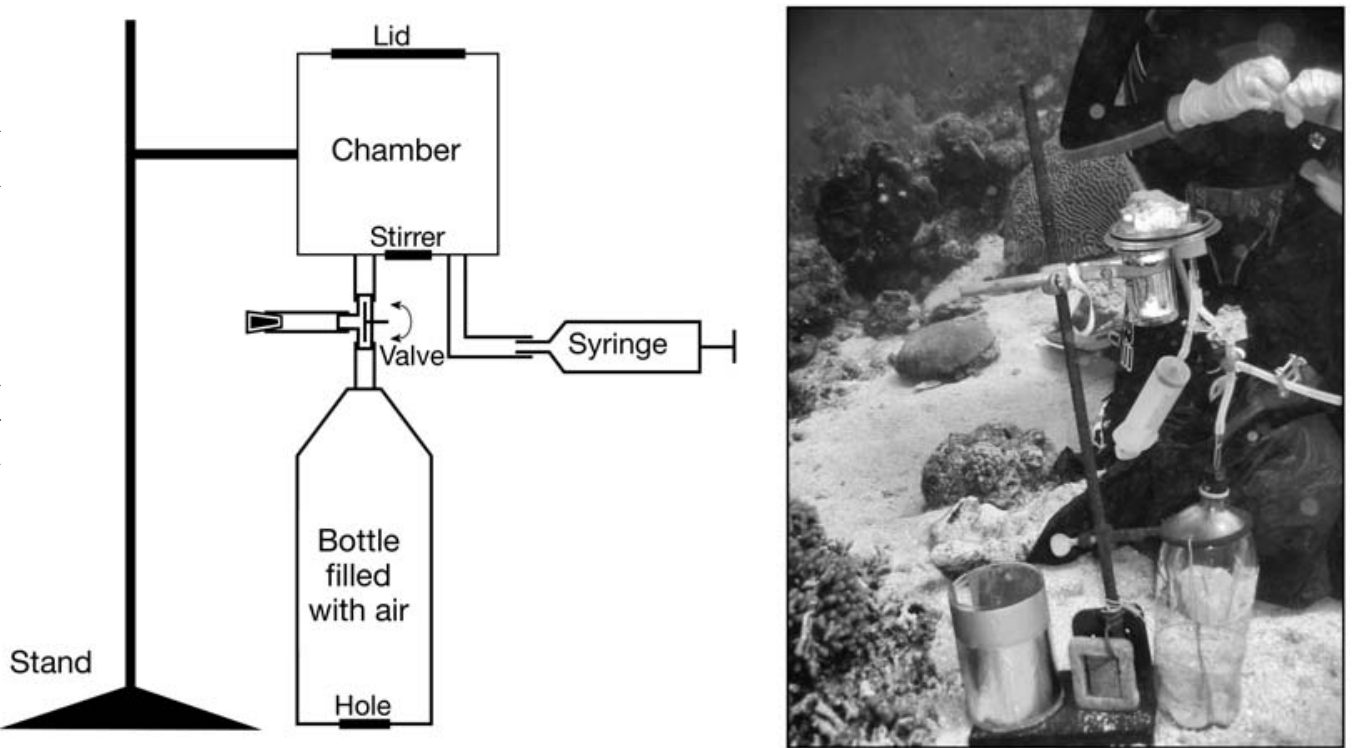

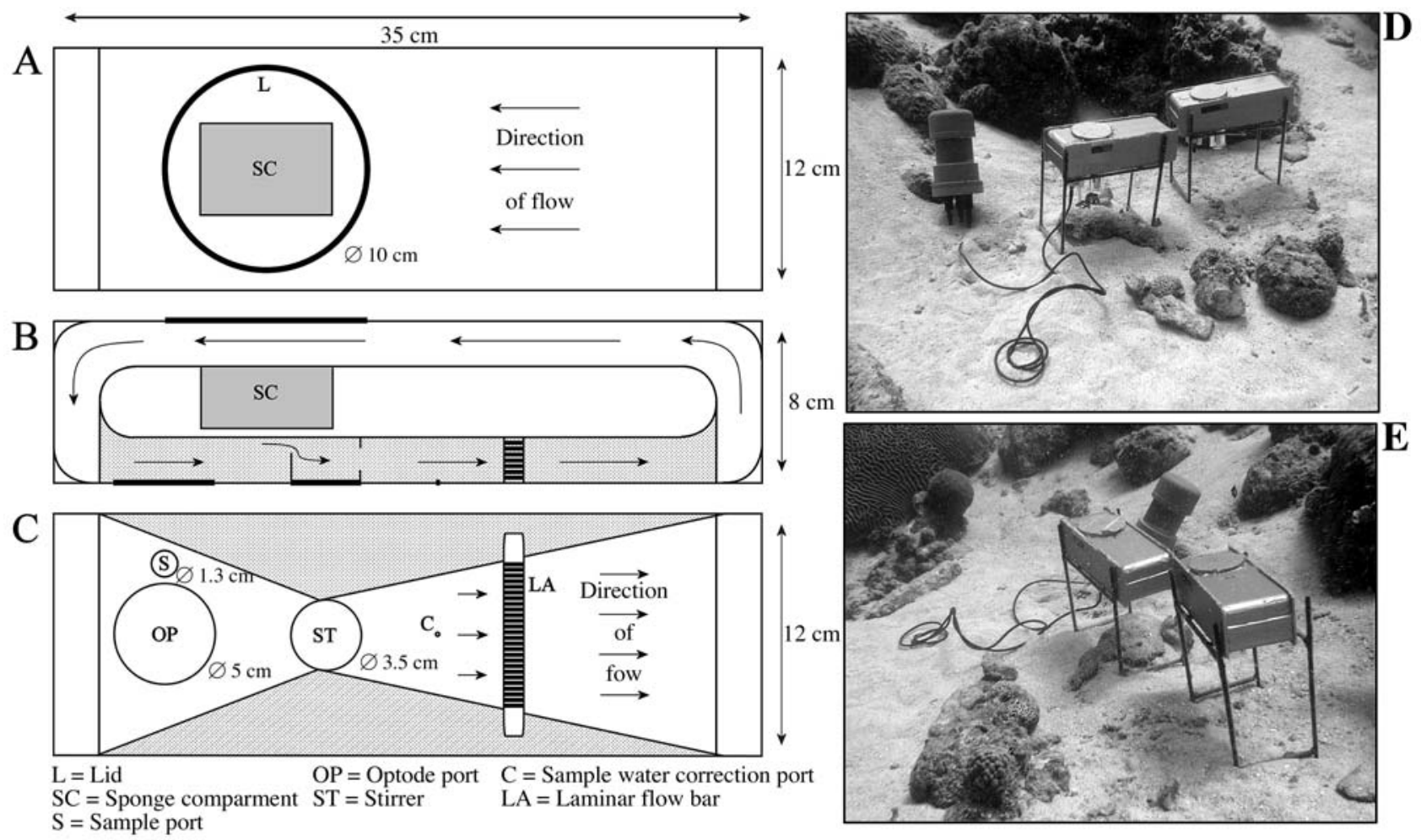

Fig. 3. Incubation Chamber 2. (A) Top, (B) side and (C) bottom views. (D,E) Flow chamber on the reef slope at approximately $12 \mathrm{~m}$ depth
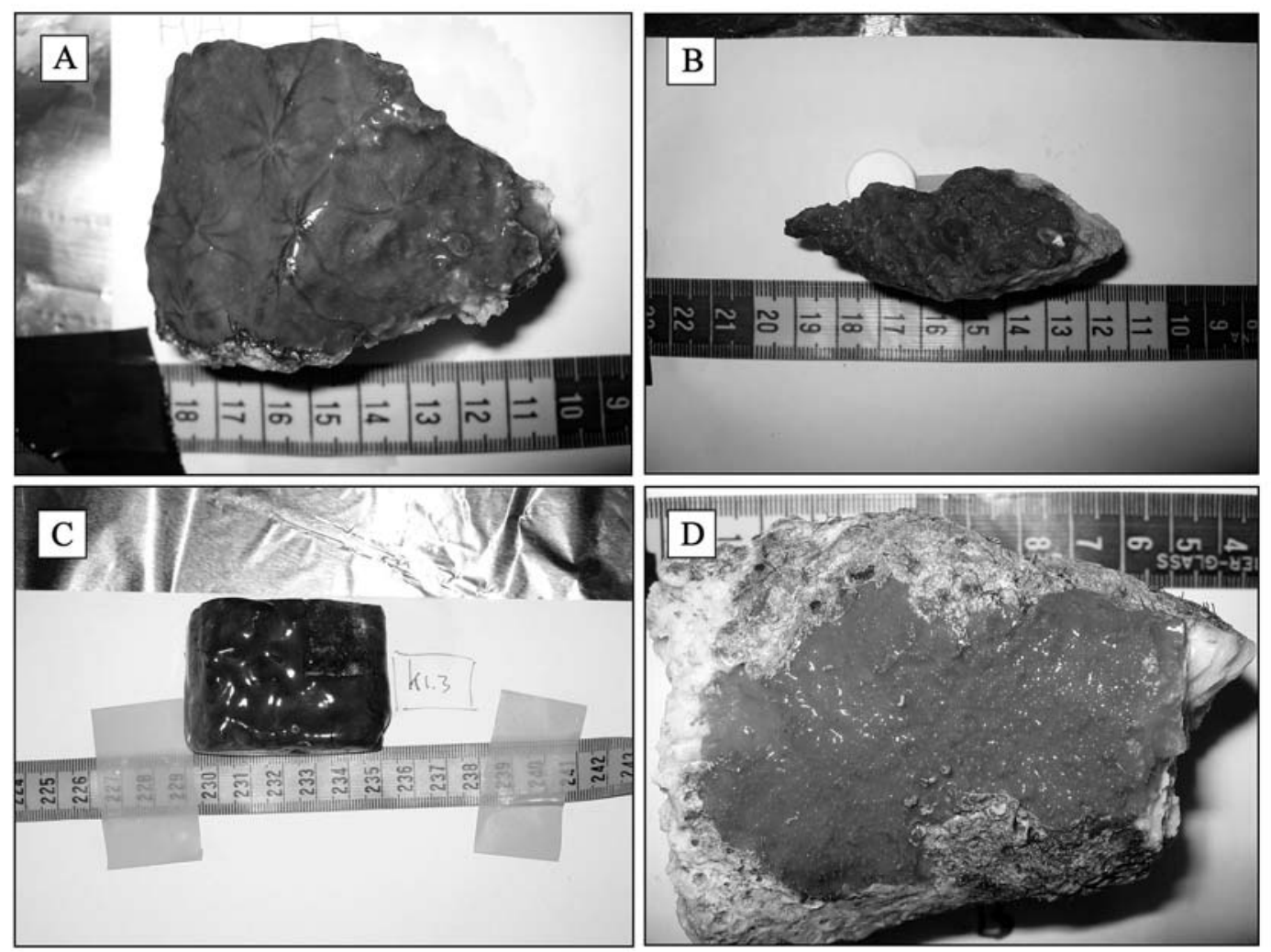

Fig. 4. (A) Halisarca caerulea, (B) Mycale microsigmatosa, (C) Halisarca caerulea shaped to fit sponge compartment of Chamber 2 and (D) Merlia normani 
syringes. Syringes were stored in the dark underwater during the experiment. Sponges were monitored for pumping activity during the experiment. After the incubation experiment, syringes were kept in the dark at $4^{\circ} \mathrm{C}$ prior to further processing within $4 \mathrm{~h}$.

In a second series of experiments, between March and June 2005 and between January and April 2006, $\mathrm{O}_{2}$, DOC and BC uptake, and DIC release by Halisarca caerulea were monitored in Chamber 2. Two control experiments (with coral rock and with ambient reef water only; $\mathrm{n}=6$ ) were performed. Before the incubation, trapped air was carefully removed from the chambers, tubings and syringes. The flow chambers were placed on a specially designed stand and were allowed to acclimatize prior to the positioning of the sponge (Fig. 3). Before closing the chamber, time $0\left(t_{0}\right)$ samples were taken for DOC and BA $(80 \mathrm{ml})$ and $\mathrm{O}_{2}(220 \mathrm{ml})$. After closing Chamber 2, samples for DOC and BA were taken at $t=5,10,30$, 60 and in some series up to $90 \mathrm{~min}$. Samples for $\mathrm{O}_{2}$ and DIC were taken at the end of each experiment. Due to the large volumes of water needed per sample, $\mathrm{O}_{2}$ and DIC concentration were determined only at $t_{0}$ and $t_{\text {end }}$. All syringes were kept underwater in the dark during the whole experiment. To determine the influence of keeping the syringes underwater during the experiments on oxygen concentration, we measured a series of $t_{0}$ oxygen samples $(\mathrm{n}=8)$ that were both kept underwater during the whole experiment as well as directly processed (brought to the surface by a second diver after sampling $t_{0}$ ). After the incubation experiment, samples for oxygen concentration were directly processed. Samples for DOC, BA and DIC were kept in the dark at $4^{\circ} \mathrm{C}$ prior to further processing within $4 \mathrm{~h}$.

Sample treatment and analysis. Water samples, collected for the determination of DOC, DIC, and BA, and sponge tissues for the determination of spongeassociated bacteria, were processed in the laboratory prior to transportation to the Netherlands for analysis. Samples for DOC and DIC analysis were gently (max. $20 \mathrm{kPa}$ suction pressure) filtered through a $0.2 \mu \mathrm{m}$ polycarbonate filter (Millipore, $47 \mathrm{~mm}$ ). Prior to filtration, filters, glassware and pipette tips were washed with acid $(3 \times 10 \mathrm{ml} 0.4 \mathrm{M} \mathrm{HCl}), 0.2 \mu \mathrm{m}$ filtered doubledistilled water $(3 \times 10 \mathrm{ml})$ and sample water $(3 \times 10 \mathrm{ml})$.

Duplicate $8 \mathrm{ml}$ DOC samples were collected in precombusted $\left(4 \mathrm{~h}\right.$ at $\left.450^{\circ} \mathrm{C}\right)$ glass ampoules. Ampoules were sealed immediately after acidification with 1 to 2 drops of concentrated $\mathrm{H}_{3} \mathrm{PO}_{4}(80 \%)$ and stored at $4^{\circ} \mathrm{C}$ until analysis. Measurements of DOC were performed by the high temperature combustion method, using a TOC Analyzer, Model TOC-5000A (Shimadzu). The TOC analyzer was calibrated with potassium phthalate in Milli-Q water. As an internal control of the DOC measurements, consensus reference material provided by D. Hansell and W. Chen of the University of Miami, USA (Batch 4, 2004; $45 \mathrm{mmol} \mathrm{l}^{-1}$, every 10 to 20 samples) was used. DOC concentrations (average $\pm \mathrm{SD}$ ) measured for the batch were $45 \pm 2 \mu \mathrm{mol} \mathrm{l} \mathrm{l}^{-1}$. The average analytical precision of the instrument was $<3 \%$ (every sample was measured 5-fold).

DIC samples $(5 \mathrm{ml})$ were transferred to glass vials (Alltech, clear screw cap $4 \mathrm{ml}$ capped with a TFE liner) amended with $10 \mu \mathrm{l}$ of a saturated $\mathrm{HgCl}_{2}$ solution $(8 \mathrm{~g}$ $100 \mathrm{ml}^{-1}$ ). Analysis of DIC was done spectrophotometrically using a continuous flow set-up run on a Technicon Traacs 80 autoanalyzer after the method of Stoll et al. (2001). The instrument was calibrated for the typical range for natural seawater (1900 to $2500 \mu \mathrm{mol} \mathrm{l}^{-1}$ ) with Certified Reference Materials (CRMs) (Godec et al. 1992).

$\mathrm{O}_{2}$ was measured according to the method of Winkler (1888), adjusted by Carpenter (1965) and Culberson (1991). Winkler bottles of approximately $60 \mathrm{ml}$ (volume of each bottle was precisely measured up to $10 \mu \mathrm{l}$ ) were rinsed $3 \times$ in seawater. Sample water of 2 syringes was carefully divided over 3 Winkler bottles (overflowing approximately $40 \mathrm{ml}$ ). Whole bottle end point titration was determined by adding a $1 \%$ starch solution using a microburette. The coefficient of variation between the triplicate measurements was $<0.5 \%$.

Samples for BA in seawater $(10 \mathrm{ml})$ were fixed in $4 \%$ paraformaldehyde (PFA), stained with acridine orange, and gently (max. $20 \mathrm{kPa}$ suction pressure) filtered onto $0.2 \mu \mathrm{m}$ black polycarbonate membrane filters (Millipore, $25 \mathrm{~mm})$, which were mounted on slides and stored at $-20^{\circ} \mathrm{C}$.

Sponge tissues for taxonomy were fixed in $5 \mathrm{ml}$ $80 \%$ ethanol. For determination of sponge-associated bacteria, sponge tissue was fixed in $3 \mathrm{ml} 4 \%$ PFA for $30 \mathrm{~min}$ at $4^{\circ} \mathrm{C}$. Subsequently, tissues were washed twice with $1 \times \mathrm{PBS}$ and stored in $5 \mathrm{ml} 1 \times \mathrm{PBS}: 80 \%$ ethanol $(1: 1)$ at $-20^{\circ} \mathrm{C}$. Sponge tissue was crushed in a reaction vial containing $200 \mu \mathrm{l}$ of Lysis T (Sigma). The dissociated cells were resuspended in $200 \mu \mathrm{l}$ of artificial sea water (ASW) and centrifuged at $2700 \times \mathrm{g}$ for $30 \mathrm{~s}$. Supernatant was collected into a $15 \mathrm{ml}$ tube. The pellet was resuspended in $10 \mathrm{ml}$ ASW, and filtered through a $0.8 \mu \mathrm{m}$ membrane filter (Millipore, $25 \mathrm{~mm}$ ), to separate sponge cells from bacterial cells. Filters were placed on a microscopic slide with a drop of DAPI-mix to stain possible retained bacteria, and stored in the dark at $-20^{\circ} \mathrm{C}$. The filtrate was added to the supernatant and diluted to $10 \mathrm{ml}$ with ASW, of which $2.5 \mathrm{ml}$ was filtered over a $0.2 \mu \mathrm{m}$ polycarbonate filter (Millipore, $25 \mathrm{~mm}$ ), supported by a $0.45 \mu \mathrm{m}$ HA filter (Millipore, $25 \mathrm{~mm}$ ). 
The filters were air dried, mounted on a microscopic slide in a DAPI-mix and stored at $-20^{\circ} \mathrm{C}$. Bacterial numbers were counted using an epifluorescence microscope $(1250 \times)$. Per slide, 10 fields were counted or up to a minimum of 200 bacteria. The DAPI counts were recalculated per $\mathrm{cm}^{3}$ sponge. Data presented in this study is only to show the presence of associated bacteria qualitatively.

Carbon uptake rates and budgets. The initial DOC removal rates by sponges were estimated by applying a 2G-model (see also de Goeij \& van Duyl 2007). DOC represents a very heterogenic group of organic compounds, both in size fractions, and chemical composition as in bioavailability or biodegradability. A simplified model to describe the course of carbon over time assumes that the DOC pool is composed of 2 major fractions. In a well mixed system, the fast $\left(C_{\mathrm{f}}\right)$ and slow $\left(C_{\mathrm{s}}\right)$ removable fractions will be consumed according to their specific fast and slow removal rate constants $k_{\mathrm{f}}$ and $k_{\mathrm{s}}$, respectively. The total DOC removal will then be described as the sum of all individual removal rates, or:

$$
\frac{\mathrm{dDOC}}{\mathrm{d} t}=-\left(k_{\mathrm{f}} C_{\mathrm{f}}+k_{\mathrm{s}} C_{\mathrm{s}}\right)
$$

By integrating this equation in reference to time, $t$, we arrive at the equation describing the concentration of DOC as a function of time:

$$
\operatorname{DOC}(t)=C_{\mathrm{f}, 0} \times \mathrm{e}^{-k_{\mathrm{f}} t}+C_{\mathrm{s}, 0} \times \mathrm{e}^{-k_{\mathrm{s}} t}
$$

The experimental data can be described using the model by estimating the model variables $C_{\mathrm{f}, 0}, k_{\mathrm{f}}, C_{\mathrm{s}, 0}$, and $k_{\mathrm{s}}$ using a minimalization routine. The initial uptake rate of DOC (the flux at $t=0$ ) was calculated from the estimated values of these variables and is given by:

$$
\text { Flux }_{\mathrm{DOC}}=-\left(k_{\mathrm{f}} C_{\mathrm{f}, 0}+k_{\mathrm{s}} C_{\mathrm{s}, 0}\right)
$$

Bacterioplankton removal rates in closed coral cavities were calculated assuming an exponential clearance of bacterial cells in a closed system with homogenous mixed water (Scheffers et al. 2004). To convert bacterial abundance to carbon biomass, a conversion factor of $30 \mathrm{fg}$ per bacterial cell was used (Fukuda et al. 1998). Clearance rates (CR) were calculated according to Riisgård et al. (1993):

$$
\mathrm{CR}=\left(V_{\mathrm{w}} / t\right) \times \ln \left(C_{0} / C_{t}\right)
$$

where $V_{\mathrm{w}}$ is water volume in the incubation chamber, $C_{0}$ and $C_{t}$ are the bacterioplankton concentrations at times 0 and $t$, calculated from the regression equation (Riisgård et al. 1993). CRs were calculated only to compare with those found in the literature.

To establish a mass balance, and to reconstruct the carbon flow for Halisarca caerulea, exchange rates for
DOC, $\mathrm{O}_{2}$ and DIC were calculated from the concentration difference between $t_{0}$ and $t_{\text {end }}$. The TOC pool is comprised of DOC and POC. POC in tropical reef water consists mainly of phytoplankton and bacterioplankton. Phytoplankton carbon removal rates were not directly measured. The contribution of phytoplankton carbon to the total $\mathrm{C}$ pool in tropical waters is low and in the same order of magnitude as bacterioplankton carbon (Ayukai 1995, Yahel et al. 1998, van Duyl et al. 2002), or lower (Richter et al. 2001, Kötter 2003). For conservancy, TOC and POC removal rates used in the mass balance were calculated as follows:

$$
\mathrm{TOC}=\mathrm{DOC}+\mathrm{POC}, \text { where POC }=2 \times \mathrm{BC}
$$

\section{RESULTS}

\section{DOC removal kinetics}

The DOC concentration decreased exponentially with time in the presence of any of the 3 sponges, regardless of the chamber used. The $2 \mathrm{G}$-model provided a fairly accurate description of the decrease in DOC concentration in the presence of the 3 sponges (Fig. 5) and was therefore applied to estimate the initial DOC removal rates for all experiments. In contrast, the concentration of DOC in the blank incubations (with ambient reef water only) did not significantly change (Fig. 5). In incubation experiments with coral rock, there was no significant removal or release of DOC (paired $t$-test; $t=0.358, \mathrm{df}=5$; not significant [ns]).

Table 1 gives the volumes of the 3 incubated encrusting sponges, based on an average thickness of $0.25 \mathrm{~cm}$, the DOC concentration at the start of each experiment and the initial removal rate. No significant differences in initial removal rates could be detected between the 3 species (Generalised Linear Models, GLM; $F=1.433, \mathrm{df}=2 ; \mathrm{ns})$. The average initial removal rates for the 3 sponges are given in Table 1 . The average $( \pm \mathrm{SD})$ initial DOC removal rate of all sponges in Chamber 1 was $14.1 \pm 2.1 \mu \mathrm{mol} \mathrm{C} \mathrm{cm}{ }^{-3}$ sponge $^{-1}$. For Halisarca caerulea, the average initial removal rates measured in Chamber $2\left(17.1 \pm 2.4 \mu \mathrm{mol} \mathrm{C} \mathrm{cm} \mathrm{cm}^{-3}\right.$ sponge $\mathrm{h}^{-1}$ ) were higher than those observed in Chamber $1\left(13.1 \pm 2.5 \mu \mathrm{mol} \mathrm{C} \mathrm{cm}{ }^{-3}\right.$ sponge $\left.^{-1}\right)(2$-sample $t$-test; $t=-3.076, \mathrm{df}=12 ; \mathrm{p}<0.025)$. This may have resulted from a (seasonal) difference in DOC composition and bio-availability, the physiological status of the sponges, and from a difference in transport efficiency (different hydrodynamical conditions due to different design) between the 2 chambers. Since the design of Chamber 2 combines the surface to volume ratio of natural cavities with optimal mixing conditions, these initial DOC removal rates were considered as maximum values. 

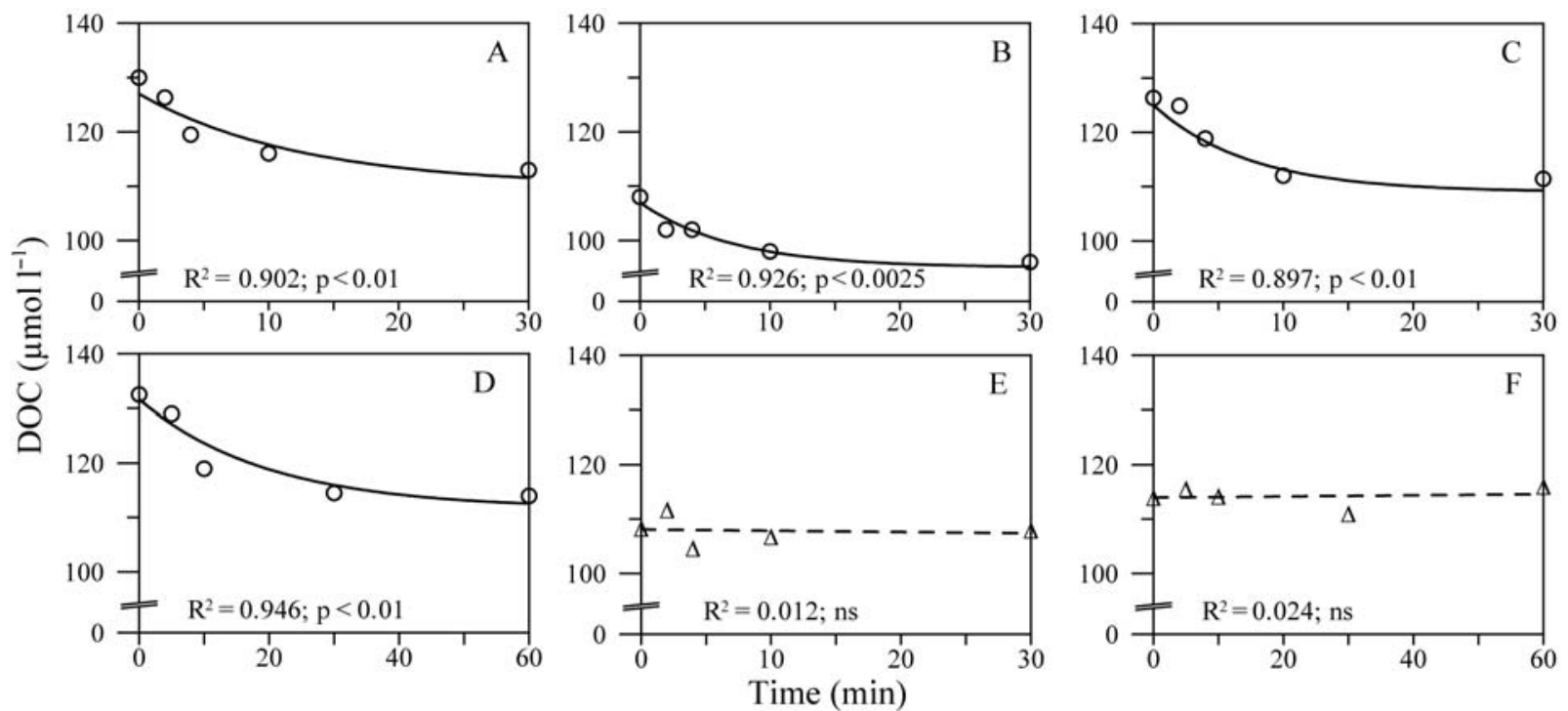

Fig. 5. Halisarca caerulea, Mycale microsigmatosa and Merlia normani. Exponential decrease in dissolved organic carbon (DOC) concentration with time for incubations with 3 encrusting sponges. Chamber 1: (A) H. caerulea Hal 2, (B) M. microsigmatosa Myc 2, (C) M. normani Mer 3. Chamber 2: (D) H. caerulea Hal 16. (E) and (F) are blank incubations in Chambers 1 and 2, respectively. Sponge designations correspond to those used in Table 1. Note that Chamber 1 incubations are up to 30 min and Chamber 2 incubations up to $60 \mathrm{~min}$. Trend lines are given by a $2 \mathrm{G}$-model fit. ns: not significant

Table 1. Halisarca caerulea, Mycale microsigmatosa and Merlia normani. Incubation experiments and average dissolved organic carbon (DOC) and bacterioplankton carbon (BC) removal rates, measured in 2 different incubation chambers. Values are average \pm SD. Hal: H. caerulea, Myc: M. microsigmatosa, Mer: M. normani; $t_{0}$ : time zero; DOC $_{2 \mathrm{G}}$ : DOC 2G-model fit; BA: bacterial abundance; $\mathrm{BC}_{\exp }$ : $\mathrm{BC}$ exponential fit; nd: no data

\begin{tabular}{|c|c|c|c|c|c|c|}
\hline Sponge & $\begin{array}{l}\text { Volume } \\
\left(\mathrm{cm}^{3}\right)\end{array}$ & $\begin{array}{c}\text { DOC } \\
t_{0} \\
\left(\mu \mathrm{mol} \mathrm{l}^{-1}\right)\end{array}$ & $\begin{array}{c}\mathrm{DOC}_{2 \mathrm{G}} \\
\text { removal rate } \\
\left(\mu \mathrm{mol} \mathrm{cm}{ }^{-3} \mathrm{~h}^{-1}\right)\end{array}$ & $\begin{array}{c}\text { BA } \\
t_{0} \\
\left(10^{5} \mathrm{~cm}^{-3}\right)\end{array}$ & $\begin{array}{c}\mathrm{BC}_{\exp } \\
\text { removal rate } \\
\left(\mu \mathrm{mol} \mathrm{cm}{ }^{-3} h^{-1}\right)\end{array}$ & $\begin{array}{c}\text { Clearance } \\
\text { rate } \\
\left(\mathrm{cm}^{3} \mathrm{~cm}^{-3} \mathrm{~min}^{-1}\right)\end{array}$ \\
\hline \multicolumn{7}{|l|}{ Chamber 1} \\
\hline Hal 1 & 4.2 & 117 & 13.4 & nd & nd & nd \\
\hline Hal 2 & 7.0 & 131 & 16.4 & 9.2 & 0.3 & 2.3 \\
\hline Hal 3 & 6.1 & 94 & 10.6 & 9.1 & 0.6 & 4.3 \\
\hline Hal 4 & 5.6 & nd & nd & 9.5 & 0.7 & 4.8 \\
\hline Hal 5 & 6.2 & nd & nd & 9.9 & 0.6 & 4.0 \\
\hline Hal 6 & 6.8 & 105 & 10.7 & 8.1 & 0.5 & 4.2 \\
\hline Hal 7 & 5.7 & 130 & 14.3 & 7.9 & 0.6 & 5.2 \\
\hline Average & & & $13.1 \pm 2.5$ & & $0.6 \pm 0.1$ & \\
\hline Мус 1 & 7.2 & 108 & 14.0 & 8.8 & 0.5 & 3.9 \\
\hline Мус 2 & 5.0 & 109 & 14.4 & 11.0 & 0.9 & 5.5 \\
\hline Myс 3 & 7.4 & 144 & 15.1 & 7.4 & 0.4 & 3.9 \\
\hline Мyс 4 & 1.9 & 154 & 15.3 & nd & nd & nd \\
\hline Myс 5 & 3.5 & 106 & 15.5 & 9.3 & 0.6 & 4.0 \\
\hline Мyс 6 & 5.0 & 105 & 16.5 & 9.1 & 0.4 & 3.0 \\
\hline Average & & & $15.2 \pm 0.9$ & & $0.6 \pm 0.1$ & \\
\hline Mer 1 & 7.6 & 136 & 11.9 & 7.3 & 0.3 & 2.9 \\
\hline Mer 2 & 3.8 & 142 & 11.8 & 8.0 & 0.3 & 2.8 \\
\hline Mer 3 & 5.8 & 126 & 17.1 & 8.3 & 0.4 & 3.5 \\
\hline Average & & & $13.6 \pm 3.1$ & & $0.4 \pm 0.1$ & \\
\hline \multicolumn{7}{|l|}{ Chamber 2} \\
\hline Hal 8 & 6.1 & 112 & 18.7 & 8.3 & 1.5 & 11.7 \\
\hline Hal 9 & 6.1 & 130 & 13.4 & 10.7 & 0.4 & 2.2 \\
\hline Hal 10 & 6.1 & 135 & 14.0 & 9.4 & 0.6 & 4.1 \\
\hline Hal 11 & 6.1 & 120 & 21.0 & 9.4 & 0.3 & 2.1 \\
\hline Hal 12 & 6.1 & 160 & 18.9 & 8.6 & 0.7 & 5.1 \\
\hline Hal 13 & 6.1 & 133 & 16.7 & 8.9 & 0.4 & 2.8 \\
\hline Hal 14 & 6.1 & 139 & 16.7 & 12.1 & 0.4 & 2.3 \\
\hline Hal 15 & 6.1 & 110 & 16.3 & 12.6 & 0.8 & 4.2 \\
\hline Hal 16 & 6.1 & 111 & 18.2 & 9.0 & 1.1 & 8.4 \\
\hline Hal 17 & 6.1 & nd & nd & 8.9 & 1.0 & 7.3 \\
\hline Average & & & $17.1 \pm 2.4$ & & $0.7 \pm 0.4$ & \\
\hline
\end{tabular}




\section{Bacterial clearance}

BA significantly decreased exponentially with time for all sponges, whereas BA did not significantly change in the control experiments without sponges (with ambient reef water only; Fig. 6). In incubation experiments with coral rock, there was no significant removal or release of DOC (paired $t$-test; $t=1.342, \mathrm{df}=$ $5 ; \mathrm{ns})$. Initial abundance, $\mathrm{BC}$ removal rate, and the clearance rates are presented in Table 1 . There was no significant difference in $\mathrm{BC}$ fluxes measured for the 3 different sponges used in Chamber 1 (GLM: $F=2.324$, $\mathrm{df}=2 ; \mathrm{ns})$. Moreover, Halisarca caerulea BC fluxes did not significantly change between Chambers 1 and 2 (2sample $t$-test, $t=-0.769, \mathrm{df}=14 ; \mathrm{ns})$. The average $( \pm \mathrm{SD})$ initial $\mathrm{BC}$ removal rate of all sponges in Chamber 1 was $0.52 \pm 0.16 \mu \mathrm{mol} \mathrm{C} \mathrm{cm}{ }^{-3}$ sponge $\mathrm{h}^{-1}$, and for $H$. caerulea in Chamber 2 was $0.70 \pm 0.38 \mu \mathrm{mol} \mathrm{C} \mathrm{cm}{ }^{-3}$ sponge $\mathrm{h}^{-1}$. The initial $\mathrm{BC}$ removal rates were 2 orders of magnitude lower than the initial DOC removal rates (Table 1). There was no correlation between size (volume) of the 3 encrusting sponges in Chamber 1 and the clearance rates (Pearson 2-tailed; $\mathrm{R}^{2}=0.0196, \mathrm{n}=14 ; \mathrm{ns}$ ).

\section{Sponge-associated bacteria}

All 3 encrusting sponges harbored sponge-associated bacteria. On average $2.1 \times 10^{9} \mathrm{~cm}^{-3}$ sponge (Haliscara caerulea), $2.1 \times 10^{9} \mathrm{~cm}^{-3}$ sponge (Mycale microsigmatosa), and $1.5 \times 10^{9} \mathrm{~cm}^{-3}$ sponge (Merlia normani) were counted with DAPI. Preliminary results of the bacterial communities of the 3 sponges determined by a catalyzed reporter deposition-fluorescence in situ hybridization (CARD-FISH) procedure on the filters (according to Pernthaler et al. [2002], adjusted by Teira et al. [2004]) show that DAPI-counts represented $76 \%(H$. caerulea), $66 \%$ (M. microsigmatosa), and 60\% (M. normani) of the CARD-FISH counts, using a probe against eubacteria (F.C. Van Duyl unpubl.). This data is only presented here to qualitatively confirm the presence of sponge-associated bacteria.

\section{Halisarca caerulea oxygen respiration}

The concentration of $\mathrm{O}_{2}$ significantly decreased with time in the presence of Haliscara caerulea (paired $t$ test, $t=8.646, \mathrm{df}=21, \mathrm{p}<0.001$ ). In the control experiment (incubation experiment with ambient reef water only), the $\mathrm{O}_{2}$ concentration significantly increased with time, at an average rate of $1.4 \mu \mathrm{mol} \mathrm{l}^{-1} \mathrm{~h}^{-1}$ (paired $t$ test, $t=-5.000, \mathrm{df}=3, \mathrm{p}<0.01$ ). In addition, the $\mathrm{O}_{2}$ concentration of sample water directly processed on board during an experiment was significantly higher than the $\mathrm{O}_{2}$ concentration of sample water kept underwater in the dark and processed at the end of an experiment (paired $t$-test, $t=8.148, \mathrm{df}=6, \mathrm{p}<0.001$ ), yielding an average water column respiration rate of $2.7 \mu \mathrm{mol} \mathrm{l}^{-1}$ $\mathrm{h}^{-1}$. The average $( \pm \mathrm{SD})$ respiration rate for $H$. caerulea, corrected for control and water column respiration, was $2.7 \pm 0.8 \mu \mathrm{mol} \mathrm{O}_{2} \mathrm{~cm}^{-3}$ sponge $\mathrm{h}^{-1}$, or $6.7 \pm$
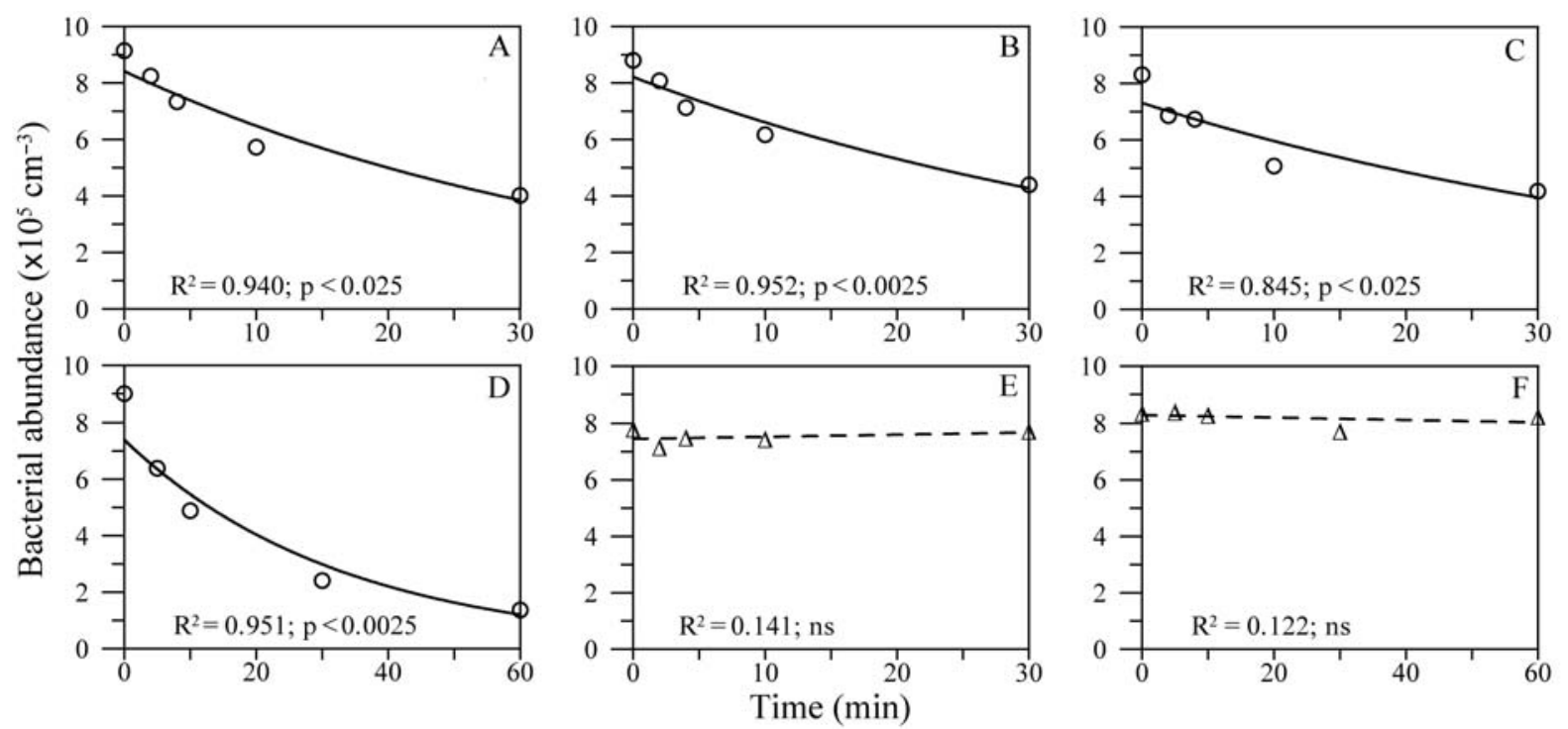

Fig. 6. Halisarca caerula, Mycale microsigmatosa and Merlia normani. Exponential decrease in bacterial abundance with time for incubations with 3 encrusting sponges. Chamber 1: (A) H. caerulea Hal 2, (B) M, microsigmatosa Myc 2, (C) M. normani Mer 3. Chamber 2: (D) H. caerulea Hal 16. (E) and (F) are blank incubations in Chambers 1 and 2, respectively. Sponge designations correspond to those used in Table 1 . Note that Chamber 1 incubations are up to 30 min and Chamber 2 incubations up to 60 min. Trend lines are given by an exponential fit. ns: not significant 
$1.9 \mathrm{mmol} \mathrm{m} \mathrm{m}^{-2} \mathrm{~h}^{-1}$ (Table 2). There was no respiration rate measured for coral rock (paired $t$-test, $t=-1.464, \mathrm{df}$ $=5 ; \mathrm{ns}$ ). During the sponge incubation experiments, the average drop in oxygen levels was $4.3 \pm 1.2 \%$ at an average initial seawater $\mathrm{O}_{2}$ concentration of $208 \pm$ $7 \mu \mathrm{mol} \mathrm{l}^{-1}\left(\mathrm{n}=22\right.$; range 196 to $\left.220 \mu \mathrm{mol} \mathrm{l}^{-1}\right)$.

\section{Halisarca caerulea DIC release}

The DIC concentration significantly increased with time in the presence of Halisarca caerulea (paired $t$ test, $t=-12.304, \mathrm{df}=12, \mathrm{p}<0.001)$. In the control incubations with ambient reef water only, the DIC concentration did not significantly change with time. However, DIC concentration significantly increased during incubations with a piece of coral rock without sponge (paired $t$-test, $t=-3.124, \mathrm{df}=4, \mathrm{p}<0.05$ ). This increase probably results from passive, chemical dissolution of $\mathrm{CaCO}_{3}$, and was on average $23 \mu \mathrm{mol} \mathrm{Cl} \mathrm{l}^{-1} \mathrm{~h}^{-1}$. In the presence of $H$. caerulea, the increase of DIC was

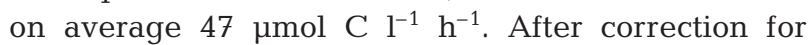
passive chemical dissolution of $\mathrm{CaCO}_{3}$, the release rate $( \pm \mathrm{SD})$ of DIC in the presence of $H$. caerulea was on average $6.4 \pm 3.3 \mu \mathrm{mol} \mathrm{C} \mathrm{cm}{ }^{-3}$ sponge $\mathrm{h}^{-1}$ (Table 2). The increase in DIC levels during the incubations was on average $0.3 \pm 0.2 \%$ at an average seawater DIC concentration of $2073 \pm 23 \mu \mathrm{mol} \mathrm{l}^{-1}(\mathrm{n}=13$, range: 2048 to $2103 \mu \mathrm{mol} \mathrm{l}^{-1}$ ).

\section{Halisarca caerulea mass balance}

More than $90 \%$ of the TOC removal by the 3 encrusting coral cavity sponges was accounted for by DOC. Although the sponges removed bacteria very efficiently on an absolute scale, the relative $\mathrm{BC}$ removal was only 2.5 to $4.1 \%$ of the TOC removal by sponges (Table 1). The contribution of POC to TOC removal was only 5.0 to $8.2 \%$, leaving 91.8 to $95 \%$ accounted for by DOC. Table 2 shows the $\Delta \mathrm{O}_{2} / \Delta \mathrm{TOC}$ and $\triangle \mathrm{DIC} / \triangle \mathrm{TOC}$ for a selection of time series. On average $( \pm \mathrm{SD})$, per mol organic $\mathrm{C}$ removed by Halisarca caerulea, $0.39 \pm 0.12 \mathrm{~mol}$ of $\mathrm{O}_{2}$ was consumed and 0.90 \pm 0.43 of DIC was released (Table 2).

\section{DISCUSSION}

\section{DOM-feeding}

Sponges are opportunistic feeders and tend to select their food on the basis of availability (Pile et al. 1996, 1997, Ribes et al. 1999). Similar to oceanic waters, DOC in the oligotrophic tropical waters represents the largest fraction of TOC, with only a minor contribution from POC. TOC in the tropical reef water of Curaçao consists mainly (average $\pm \mathrm{SD})$ of DOC $(118.4 \pm 20.5$ $\mu \mathrm{mol} \mathrm{l}{ }^{-1}$, range 63 to $\left.160, \mathrm{n}=46\right), \mathrm{BC}\left(2.1 \pm 0.4 \mu \mathrm{mol} \mathrm{l}^{-1}\right.$, range 1.1 to $3.1, \mathrm{n}=47$ ), and phytoplankton carbon (PC) (measured as chlorophyll a) $\left(0.9 \pm 0.2 \mu \mathrm{mol} \mathrm{l}^{-1}\right.$, range 0.6 to $1.1, \mathrm{n}=41$ ) (Van Duyl et al. 2002, De Goeij \& Van Duyl 2007, this study). In our incubation experiments the DOC is clearly removed in (at least) 2 major fractions, where a large part (the slow removable fraction) of DOC is not available to the sponge in the time frame of the incubation. The residence time of water in the coral cavities (the natural environment of the sponges) is in the order of minutes (Van Duyl et al. 2006), suggesting that the slow removable fraction in our model is, on average, not readily available as a source of carbon for the cavity sponges. For the 3

Table 2. Halisarca caerulea. Fate of organic carbon for $H$. caerulea. The concentration of DOC, BC, $\mathrm{O}_{2}$ and DIC were measured simultaneously per incubation, and the $\Delta \mathrm{O}_{2} / \Delta \mathrm{TOC}$ and $\Delta \mathrm{DIC} / \Delta \mathrm{TOC}$ calculated. Values are average \pm SD. Note that fluxes of DOC, POC, TOC, and $\mathrm{O}_{2}$ are removal rates and DIC is a release rate

\begin{tabular}{|c|c|c|c|c|c|c|c|}
\hline Date & DOC & POC & 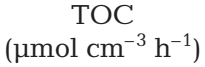 & $\mathrm{O}_{2}$ & DIC & $\Delta \mathrm{O}_{2} / \Delta \mathrm{TOC}$ & $\Delta \mathrm{DIC} / \Delta \mathrm{TOC}$ \\
\hline 06 Jun 05 & 8.3 & 3.0 & 11.3 & 3.2 & 8.9 & 0.29 & 0.79 \\
\hline 23 Jun 05 & 3.3 & 0.8 & 4.1 & 2.0 & 2.7 & 0.49 & 0.66 \\
\hline 24 Jun 05 & 5.3 & 1.2 & 6.5 & 4.0 & 2.8 & 0.62 & 0.43 \\
\hline 06 Apr 06 & 6.9 & 0.6 & 7.5 & 2.2 & 10.8 & 0.29 & 1.43 \\
\hline 07 Apr 06 & 6.9 & 1.4 & 8.3 & 3.4 & 7.4 & 0.41 & 0.89 \\
\hline 07 Apr 06 & 5.1 & 0.8 & 5.9 & 2.5 & 6.6 & 0.43 & 1.12 \\
\hline 10 Apr 06 & 5.3 & 0.8 & 6.1 & 1.9 & 9.5 & 0.31 & 1.55 \\
\hline 10 Apr 06 & 6.1 & 1.6 & 7.7 & 3.0 & 1.8 & 0.38 & 0.24 \\
\hline 13 Apr 06 & 5.3 & 2.2 & 7.5 & 1.9 & 7.4 & 0.26 & 0.99 \\
\hline Average & $5.9 \pm 1.4$ & $1.4 \pm 0.8$ & $7.2 \pm 2.0$ & $2.7 \pm 0.8$ & $6.4 \pm 3.6$ & $0.39 \pm 0.12$ & $0.90 \pm 0.43$ \\
\hline $\begin{array}{l}\text { Average } \\
\left(\mathrm{mmol} \mathrm{m}^{-2} \mathrm{~h}^{-1}\right)\end{array}$ & $14.6 \pm 3.6$ & $3.4 \pm 2.0$ & $18.0 \pm 4.9$ & $6.7 \pm 1.9$ & $16.1 \pm 8.1$ & & \\
\hline
\end{tabular}


encrusting coral cavity sponges studied here, the amount of DOC uptake in relation to TOC intake is comparable with values found for the sponge Theonella swinhoei (Yahel et al. 2003). In fact, in both studies, more than $90 \%$ of the TOC removed by the sponges is accounted for by DOC, suggesting that these species, in spite of being classified as particle feeders, are (in quantitative terms related to the availability of organic carbon sources) actually 'DOMfeeders'. This supports the suggestion by Reiswig $(1974 b, 1981)$ that DOC uptake may explain the $>70 \%$ discrepancy between the particulate gain and respiratory demand of several tropical sponges.

Little is known about the uptake mechanism for DOM in sponges. It has been suggested that only sponges with large amounts of sponge-associated bacteria can utilize DOM. The 3 encrusting sponge species used in this report indeed harbor spongeassociated bacteria. Tritium labelled proline was more rapidly incorporated into symbiotic bacteria of the marine sponge Chondrosia reniformis, than in sponge cells (Wilkinson \& Garrone 1979). However, in Theonella swinhoei (Magnino et al. 1999), Verongia fistularis (Reiswig 1981), and in the 3 sponge species presented in this report, most sponge-associated bacteria reside in the mesohyl and are not in direct contact with the passing water, and the removed DOM is likely to pass sponge cells first. Sponges feed by using flagellated cells (choanocytes) lining the choanocyte chambers, which constitute the basic pumping and filtering elements. The sponge choanocytes are functionally comparable to choanoflagellates, which are closely related with sponges (Leys \& Eerkes-Medrano 2006 and references therein). Flagellates can ingest a variety of macromolecules, including carbohydrates and proteins, components of the colloidal fraction of DOM (Tranvik et al. 1993). Choanoflagellates can feed on high molecular weight molecules (Sherr 1988, Christoffersen et al. 1996) and have been demonstrated to prefer smaller sized (viral-sized) particles (50 nm latex beads) over larger bacterial-sized beads (500 nm latex beads) (Marchant 1990, Gonzalez \& Suttle 1993). Sponges have been reported to take up virus particles (Hadas et al. 2006), and to remove $0.1 \mu \mathrm{m}$ beads from ambient water (Leys \& EerkesMedrano 2006). At least $10 \%$ of oceanic DOM is in the form of amorphous detrital particles in the size range 0.4 to $1.0 \mu \mathrm{m}$ that easily pass the pores of the $0.2 \mu \mathrm{m}$ filters employed in the separation of DOM and POM (Koike et al. 1990). It is possible that sponge choanocytes take up particles, to molecular weight size range, residing in the dissolved fraction mainly in colloidal form and transport part of the DOM to the spongeassociated bacteria in the mesohyl. First evidence from experiments with ${ }^{13} \mathrm{C}$ enriched DOC substrate show that both sponge cells and associated bacteria can assimilate DOM (De Goeij et al. 2008). It is not yet clear to what extent (quantitatively and qualitatively) the sponge cells or the associated bacteria cells are involved in the utilization and metabolism of DOM, therefore 'DOM-feeding by sponges' should be more appropriately described as: 'DOM-feeding by the sponge-microbe association'.

\section{Carbon removal rates}

The total carbon removal rates by the 3 cryptic encrusting sponges presented in this study are the highest ever reported. Ingestion rates reported in the literature range from 0.08 to $1.97 \mathrm{~g} \mathrm{C} \mathrm{m}^{-2}$ sponge $\mathrm{d}^{-1}$ (Gili \& Coma 1998 and references therein) and 0.04 to $1.80 \mu \mathrm{mol} \mathrm{cm}{ }^{-3}$ sponge $\mathrm{h}^{-1}$ (Yahel et al. 2003 and references therein). Assuming an average daily pumping activity of $12 \mathrm{~h}$ (Pile et al. 1997) yields a carbon flux of 5.15 to $6.66 \mathrm{~g} \mathrm{C} \mathrm{m}^{-2}$ sponge $\mathrm{d}^{-1}$. Fluxes per volume of sponge in the present study range between 14.3 to $18.5 \mu \mathrm{mol} \mathrm{C} \mathrm{cm}{ }^{-3}$ sponge $\mathrm{h}^{-1}$. To our knowledge there is only one study on extensive DOC removal by sponges, reporting the highest total carbon intake rates at that time (Yahel et al. 2003). Since other studies do not report DOM fluxes (Reiswig 1971, Pile et al. 1996, 1997, Kötter \& Pernthaler 2002), or did not find DOM retention in sponge species lacking bacterial symbionts (Ribes et al. 1999, Yahel et al. 2007), it is difficult to compare total carbon fluxes. Nonetheless, the fluxes presented here are very high compared to published values. The estimated clearance rates (in $\mathrm{cm}^{3}$ water $\mathrm{cm}^{-3}$ sponge $\mathrm{min}^{-1}$ ) of Halisarca caerulea (2.1 to 11.7), Mycale microsigmatosa (3.0 to 5.5) and Merlia normani (2.8 to 3.5), however, are in the range of values $( \pm \mathrm{SD})$ reported in the literature, of $2.5 \pm 1.7$ for the sponge Haliclona ureolus (range 1.1 to 6.0; Riisgård et al. 1993). Kötter \& Pernthaler (2002) reported average clearance rates for $H$. caerulea $(6.1 \pm 4.6)$ and $M$. normani $(2.5 \pm 1.1)$, so there is no reason to suspect abnormal clearance capacity of the 3 sponges used in this study. Rates of BC removal (in $\mu$ mol $\mathrm{C} \mathrm{cm}^{-3} \mathrm{~h}^{-1}$ ) for tropical encrusting sponges is on average 0.75 (Kötter \& Pernthaler 2002), close to our average BC removal rates by encrusting sponges of 0.59 (Tables 1 \& 2). Kötter \& Pernthaler (2002) found removal rates of BC for $H$. caerulea ranging from 0.33 to 1.17 and for $M$. normani ranging from 0.59 to 0.88 . We found $\mathrm{BC}$ fluxes of 0.60 to 2.92 and 0.62 to 0.88 for $H$. caerulea and M. normani respectively. Again, the feeding behavior of the 3 encrusting sponges does not seem to be out of range.

Size and body morphology of sponges can have an effect on clearance rates (Reiswig 1974b, Riisgård et al. 1993, Ribes et al. 1999), but also on the supply of 
certain food fractions and, thus, the capability of feeding on different sized particles (Abelson et al. 1993), such as DOM (Yahel et al. 2003). Clearance rates have been observed to decrease with increasing sponge size (Reiswig 1974b, Riisgård et al. 1993, Ribes et al. 1999). We did not find any correlation between sponge size (in the measured size range 1.9 to $7.6 \mathrm{~cm}^{3}$ ) and clearance rates, but cannot exclude that larger sized sponges in the field (ranging $<1 \mathrm{~cm}^{3}$ to $>100 \mathrm{~cm}^{3}, \mathrm{~J}$. M. de Goeij pers. obs.) have lower clearance rates and might effect community organic carbon removal. The high surface:volume ratio of encrusting sponges as compared with massive sponges is suggested to increase their retention efficiency (Kötter 2003), and the ability of invertebrates to ingest DOC (Siebers 1982). The sheet-like body form can have a competitive edge over more massive growth forms in the particle depleted coral cavities.

\section{Mass balance and fate of carbon}

The $\mathrm{O}_{2}$ respiration rates for Halisarca caerulea (in umol $\mathrm{O}_{2} \mathrm{~cm}^{-3}$ sponge $\mathrm{h}^{-1}$ ) are within the range of reported values for other sponges (1.82 to 3.98 and 0.21 to 24.6 , respectively) reviewed by Osinga 1999, and comparable with reported rates for $H$. caerulea (1.56 to 2.67) measured by Kötter \& Pernthaler (2002). $H$. caerulea has a $\Delta \mathrm{O}_{2} / \Delta \mathrm{TOC}$ of 0.39 , or $39 \%$ of the ingested carbon is respired. Assuming a respiratory quotient of 1 , this would yield a $\triangle \mathrm{DIC} / \Delta \mathrm{TOC}$ value of 0.39 , whereas a value of 0.90 (corrected for passive chemical dissolution) has been observed. We argue that the excess DIC release is not due to possible coral rock metabolism by epi- or infauna, since the coral rock (cleared of epibionts) did not remove or release any DOC, BC, or oxygen. Excess DIC release is attributed to $H$. caerulea respiration driven dissolution of the attached coral rock. Dissolution of $\mathrm{CaCO}_{3}$ increases DIC by $1 \mathrm{~mol}$ for each mol of calcium carbonate dissolved (Gattuso et al. 1995), leaving a $\Delta \mathrm{DIC} / \Delta \mathrm{TOC}$ for $H$. caerulea respiration of 0.45 . The similarity between $\mathrm{O}_{2}$-based respiration estimation (39\%) and $\mathrm{CO}_{2}$-based respiration estimation (45\%) illustrates the accuracy for the $H$. caerulea carbon mass balance.

To determine the fate of carbon it is assumed that $1 \mathrm{~mol}$ of organic $\mathrm{C}$ removed is respired by $1 \mathrm{~mol}$ of $\mathrm{O}_{2}$. The discrepancy between total organic carbon uptake and oxygen respiration can be explained by microbial processes like sulfate reduction (Hoffmann et al. 2005), or fermentation (Santavy et al. 1990). Fermentation is a common feature in benthic invertebrates (Grieshaber et al. 1994). Alternatively, or in addition, the fate of the removed organic carbon is determined by assimilation.
If it is assumed that Halisarca caerulea respires approximately 39 to $45 \%$ of the removed organic carbon, then 55 to $61 \%$ of the removed organic carbon can be used for growth, reproduction or the production of metabolites. The net increase of cryptic sponge biomass is not likely to be high. Competition for space is high in coral cavities (Jackson et al. 1971) and especially for the thin encrusting species, which are highly surface-dependent, and growth and mortality rates are influenced by strong space competition with neighbours (Turon et al. 1998). If more than half of the carbon uptake is assimilated by $H$. caerulea, but net growth is close to 0 , then a rapid turnover of biomass is suggested. Encrusting sponges are known to have a high plasticity, or regeneration capacity, with growth rates of 2900 times the normal growth rate after tissue damage (Ayling 1983), showing that the potential for rapid cell proliferation is present. The resulting cell remnants could have been missed from our incubation measurements, because they are likely to be exported as detrital particulate carbon, which we did not measure. Both Reiswig (1971) and Yahel et al. (2003) found significant excretion of detrital material by the examined sponges (possible sponge cell material or faeces). Decomposition by the deep-sea sponge community of particles $>2 \mu \mathrm{m}$ was argued to have a major contribution to the total sedimentation rate of the Greenland-Iceland-Norwegian (GIN) seas (Witte et al. 1997)

\section{Sponges and coral cavities}

The cryptic coral reef framework is a significant sink of carbon, where most (>90\%) of the removed carbon is accounted for by the dissolved fraction. The flux of carbon even exceeds the estimated gross production of the reef (De Goeij \& Van Duyl 2007). But which organisms are responsible for this important carbon retention in cryptic habitats? The walls of coral cavities are covered by highly abundant groups of coelobites, such as coralline algae, ascidians, bryozoans and polychaetes. To directly link the organic carbon removal of sponges with coral cavities, qualitatively and quantitatively, the activity of other compartments of the cavity (e.g. benthic communities on cavity walls and in the sediment) has to be included in the carbon budget. The cover is, however, dominated by encrusting sponges (Wunsch et al. 2000, Richter et al. 2001, van Duyl et al. 2006). In the present study, the encrusting cryptic sponges Halisarca caerulea, Mycale microsigmatosa, and Merlia normani remove carbon of which the largest part $(>90 \%)$ is DOC, comparable to organic carbon removal by coral cavities. It is likely that the removal of DOC by the reef framework is influenced 
by the removal of DOC by cavity sponges. Thus, a thin veneer of encrusting sponges, only a few millimetres thick, may play a key role in organic carbon removal by coral cavities and thus in the overall carbon cycling of coral reefs.

Acknowledgements. We thank the CARMABI Foundation staff (Curaçao, Netherlands Antilles) and especially C. Winterdaal and B. Leysner for their hospitality and support. We thank J. W. van Dam and A. de Kluijver for their help in the field. A special thanks to S. Gonzalez for analyzing the DOC samples. K. Bakker, J. van Ooijen and E. van Weerlee are acknowledged for the analysis of the DIC samples. The laminar flow chamber was constructed by Eiso Bergsma BV, Amsterdam, The Netherlands. R. W. M. van Soest is acknowledged for sponge taxonomy. This study was financed by the Netherlands Organization for Scientific Research (NWOWOTRO grant no. W84-547).

\section{LITERATURE CITED}

Abelson A, Miloh T, Loya Y (1993) Flow patterns induced by substrata and body morphologies of benthic organisms, and their role in determining availability of food particles. Limnol Oceanogr 38:1116-1124

Ayling AL (1983) Growth and regeneration rates in thinly encrusting demospongiae from temperate waters. Biol Bull 165:343-352

Ayukai T (1995) Retention of phytoplankton and planktonic microbes on coral reefs within the Great Barrier Reef, Australia. Coral Reefs 14:141-147

Carpenter JH (1965) The Chesapeake Bay Institute technique for the Winkler dissolved oxygen method. Limnol Oceanogr 10:141-143

Christoffersen K, Bernard C, Ekebom J (1996) A comparison of the ability of different heterotrophic nanoflagellates to incorporate dissolved macromolecules. Arch Hydrobiol 48:73-84

Culberson CH (1991) Dissolved oxygen. WOCE Operations and Methods 3:1-14. Available at http://whpo.uscd.edu/ manuals.htm

De Goeij JM, Van Duyl FC (2007) Coral cavities are sinks of dissolved organic matter (DOM). Limnol Oceanogr 52: 2608-2617

De Goeij JM, Moodley L, Houtekamer M, Carballeira NM, Van Duyl FC (2008) Tracing ${ }^{13} \mathrm{C}$-enriched dissolved and particulate carbon in Halisarca caerulea, a coral reef sponge with associated bacteria: evidence for DOM-feeding. Limnol Oceanogr (in press)

Frost BW (1987) Porifera. In: Pandian TJ, Vernberg FJ (eds) Animal energetics, Vol 1. Academic Press, London, p 27-53

Fukuda R, Ogawa H, Nagata T, Koike I (1998) Direct determination of carbon and nitrogen contents of natural bacterial assemblages in marine environments. Appl Environ Microbiol 64:3352-3358

> Gattuso JP, Pichon M, Frankignoulle M (1995) Biological control of air-sea $\mathrm{CO}_{2}$ fluxes: effect of photosynthetic and calcifying marine organisms and ecosystems. Mar Ecol Prog Ser 129:307-312

Gili JM, Coma R (1998) Benthic suspension feeders: their paramount role in littoral marine food webs. Trends Ecol Evol 13:316-321

Godec R, O'Neill K, Hutte R (1992) New technology for TOC analysis in water. Ultrapure Water 9:17-22
Gonzalez JM, Suttle CA (1993) Grazing by marine nanoflagellates on viruses and virus-sized particles: ingestion and digestion. Mar Ecol Prog Ser 94:1-10

Grieshaber MK, Hardewig I, Kreutzer U, Pörtner HO (1994) Physiological and metabolic responses to hypoxia in invertebrates. Rev Physiol Biochem Pharmacol 125:43-147

Hadas E, Marie D, Shpigel M, Ilan M (2006) Virus predation by sponges is a new nutrient-flow pathway in coral reef food webs. Limnol Oceanogr 51:1548-1550

Hoffmann F, Larsen O, Thiel V, Rapp HT, Pape T, Michaelis W, Reitner J (2005) An anaerobic world in sponges. Geomicrobiol J 22:1-10

Jackson JBC, Goreau TF, Hartman WD (1971) Recent brachiopod-coralline sponge communities and their paleoecological significance. Science 173:623-625

Jørgensen CB (1976) August Pütter, August Krogh, and modern ideas on the use of dissolved organic matter in aquatic environments. Biol Rev Camb Phil Soc 51:291-328

Koike I, Shigemitsu H, Kazuki T, Kazuhiro K (1990) Role of sub-micrometre particles in the ocean. Nature 345: $242-244$

Kötter I (2003) Feeding ecology of coral reef sponges. PhD thesis, Universität Bremen

Kötter I, Pernthaler J (2002) In situ feeding rates of obligate and facultative coelobite (cavity-dwelling) sponges in a Caribbean coral reef. Proc 9th Int Coral Reef Symp $1: 347-352$

Leys SP, Eerkes-Medrano DI (2006) Feeding in a calcareous sponge: particle uptake by pseudopodia. Biol Bull 211:157-171

Magnino G, Sarà A, Lancioni T, Gaino E (1999) Endobionts of the coral reef sponge Theonella swinhoei (Porifera, Demospongiae). Invertebr Biol 118:213-220

Marchant HJ (1990) Grazing rate and particle size selection by the choanoflagellate Diaphanoeca grandis from the sea-ice of lagoon Saroma Ko, Hokkaido. Proc NIPR Symp Polar Biol 3:1-7

Osinga R (1999) Cultivation of marine sponges. Mar Biotechnol 1:509-532

Pernthaler A, Pernthaler J, Amann R (2002) Fluorescence in situ hybridization and catalyzed reporter deposition for the identification of marine bacteria. Appl Environ Microbiol 68:3094-3101

Pile AJ, Patterson MR, Witman JD (1996) In situ grazing on plankton $<10 \mu \mathrm{m}$ by the boreal sponge Mycale lingua. Mar Ecol Prog Ser 141:95-102

Pile AJ, Patterson MR, Savarese M, Chernykh VI, Fialkov VA (1997) Trophic effects of sponge feeding within Lake Baikal's littoral zone. 2. Sponge abundance, diet, feeding efficiency, and carbon flux. Limnol Oceanogr 42:178-184

Reiswig HM (1971) Particle feeding in natural populations of three marine demosponges. Biol Bull 141:568-591

Reiswig HM (1974a) Bacteria as food for temperate-water marine sponges. Can J Zool 53:582-589

Reiswig HM (1974b) Water transport, respiration and energetics of three tropical marine sponges. J Exp Mar Biol Ecol 14:231-249

Reiswig HM (1981) Partial carbon and energy budgets of the bacteriosponge Verongia fistularis (Porifera: Demospongiae) in Barabados. PSZN I: Mar Ecol 2:273-293

Ribes M, Coma R, Gili JM (1999) Natural diet and grazing rate of the temperate sponge Dysidea avara (Demospongiae, Dendroceratida) throughout an annual cycle. Mar Ecol Prog Ser 176:179-190

Ribes M, Coma R, Atkinson MJ, Kinzie RA III (2005) Sponges and ascidians control removal of particulate organic nitrogen from coral reef water. Limnol Oceanogr 50:1480-1489 
Richter C, Wunsch M, Rasheed M, Kötter I, Badran MI (2001) Endoscopic exploration of Red Sea coral reefs reveals dense populations of cavity-dwelling sponges. Nature 413:726-730

Riisgård HU, Thomassen S, Jakobsen H, Weeks JM, Larsen PS (1993) Suspension feeding in marine sponges Halichondria panicea and Haliclona urceolus: effects of temperature on filtration rate and energy cost of pumping. Mar Ecol Prog Ser 96:177-188

Santavy DL, Willenz P, Colwell RR (1990) Phenotypic study of bacteria associated with the caribbean sclerosponge, Ceratoporella nicholsoni. Appl Environ Microbiol 56: $1750-1762$

Scheffers SR, Nieuwland G, Bak RPM, van Duyl FC (2004) Removal of bacteria and nutrient dynamics within the coral reef framework of Curaçao (Netherlands Antilles). Coral Reefs 23:413-422

Sherr EB (1988) Direct use of high molecular weight polysaccharide by heterotrophic flagellates. Nature 335: 348-351

Siebers D (1982) Bacterial-invertebrate interactions in uptake of dissolved organic matter. Am Zool 22:723-733

Stephens GC, Schinske RA (1961) Uptake of amino acids by marine invertebrates. Limnol Oceanogr 6:175-181

Stoll MHC, Bakker K, Nobbe GH, Haese RR (2001) Continuous-flow analysis of dissolved inorganic carbon content in seawater. Anal Chem 73:4111-4116

Teira E, Reinthaler T, Pernthaler A, Pernthaler J, Herndl GJ (2004) Combining catalyzed reporter deposition-fluorescence in situ hybridization and microautoradiography to detect substrate utilization by Bacteria and Archaea in the deep ocean. Appl Environ Microbiol 70:4411-4414

Thomas JD (1997) The role of dissolved organic matter, particularly free amino acids and humic substances, in freshwater ecosystems. Freshw Biol 38:1-36

Tranvik LJ, Sherr EB, Sherr BF (1993) Uptake and utilization of 'colloidal DOM' by heterotrophic flagellates in seawater. Mar Ecol Prog Ser 92:301-309

Turon X, Galera J, Uriz MJ (1997) Clearance rates and aquiferous systems in two sponges with contrasting life-history strategies. J Exp Zool 278:22-36

Turon X, Tarjuelo I, Uriz MJ (1998) Growth dynamics and mortality of the encrusting sponge Crambe crambe (Poe-

Editorial responsibility: Otto Kinne, Oldendorf/Luhe, Germany cilosclerida) in contrasting habitats: correlation with population structure and investment in defense. Funct Ecol 12:631-639

> Vacelet J, Boury-Esnault N (1995) Carnivorous sponges. Nature 373:333-335

Van de Vyver G, Vray B, Belauane S, Toussaint D (1990) Efficiency and selectivity of microorganism retention by Ephydatia fluviatilis. In: Rützer K (ed) New perspectives in sponge biology. Smiths Inst Press, Washington, DC, p 511-515

Van Duyl FC, Gast GJ, Steinhoff W, Kloff S, Veldhuis MJW, Bak RPM (2002) Factors influencing the short-term variation in phytoplankton composition and biomass in coral reef waters. Coral Reefs 21:293-306

Van Duyl FC, Scheffers SR, Thomas FIM, Driscoll M (2006) The effect of water exchange on bacterioplankton depletion and inorganic nutrient dynamics in coral reef cavities. Coral Reefs 25:23-36

Wilkinson C, Garrane R (1980) Nutrition of marine sponges. In: Smith DC, Tiffon Y (eds) Nutrition in the lower metazoa. Pergamon Press, Oxford, p 157-167

Winkler LW (1888) Die Bestimmung des im Wasser gelösten Sauerstoffes. Ber Dtsch Chem Ges 21:2843-2855

Witte U, Brattegard T, Graf G, Springer B (1997) Particle capture and deposition by deep-sea sponges from the Norwegian-Greenland Sea. Mar Ecol Prog Ser 154:241-252

Wright SH, Manahan DT (1989) Integumental nutrient uptake by aquatic organisms. Annu Rev Physiol 51:585-600

Wunsch M, Al-Moghrabi SM, Kötter I (2000) Communities of coral reef cavities in Jordan, Gulf of Aqaba (Red Sea). Proc 9th Int Coral Reef Symp 1:595-600

Yahel G, Post AF, Fabricius K, Marie D, Vaulot D, Genin A (1998) Phytoplankton distribution and grazing near coral reefs. Limnol Oceanogr 43:551-563

Yahel G, Sharp JH, Marie D, Haese C, Genin A (2003) In situ feeding and element removal in the symbiont-bearing sponge Theonella swinhoei: bulk DOC is the major source for carbon. Limnol Oceanogr 48:141-149

Yahel G, Whitney F, Reiswig HM, Eerkes-Medrano DI, Leys SP (2007) In situ feeding and metabolism of glass sponges (Hexactinellida, Porifera) studied in a deep temperate fjord with a remotely operated submersible. Limnol Oceanogr 52:428-440

Submitted: May 25, 2007; Accepted: January 14, 2008 Proofs received from author(s): March 7, 2008 